\title{
Potential mechanisms of hemorrhagic stroke in elderly COVID-19
}

\section{patients}

\author{
Haili Wang ${ }^{1,2,{ }^{*}}$, Xiaojia Tang ${ }^{1,2, *}$, Hongyang Fan ${ }^{1, *}$, Yuhan Luo ${ }^{1,2}$, Yuxia Song ${ }^{1,2}$, Yao Xu${ }^{1}$, Yingzhu \\ Chen $^{1}$ \\ ${ }^{1}$ Department of Neurology, Clinical Medical College, Yangzhou University, Yangzhou 225000, Jiangsu, China \\ ${ }^{2}$ Department of Neurology, Clinical Medical College of Yangzhou, Dalian Medical University, Yangzhou 225000, \\ Jiangsu, China \\ *Equal contribution and Co-first authors
}

Correspondence to: Yingzhu Chen, Yao Xu; email: yzchendr@163.com, yzxyao@yahoo.com Keywords: COVID-19, SARS-CoV-2, hemorrhagic stroke, ACE2, immunity

Received: March 11, 2020 Accepted: May 14, $2020 \quad$ Published: June 11, 2020

Copyright: Wang et al. This is an open-access article distributed under the terms of the Creative Commons Attribution License (CC BY 3.0), which permits unrestricted use, distribution, and reproduction in any medium, provided the original author and source are credited.

\section{ABSTRACT}

The novel severe acute respiratory syndrome coronavirus 2 is the causative agent of coronavirus disease 2019, a new human infectious disease. While fever, cough, and respiratory distress are typical first symptoms, a fraction of those affected present instead with neurological symptoms suggestive of central nervous system compromise. This review summarizes the potential contribution of coronavirus disease 2019 to hemorrhagic stroke in the elderly and proposes possible mechanisms. Reports show that the most affected patients have underlying chronic diseases such as hypertension and diabetes, which are two key risk factors for hemorrhagic stroke. Angiotensin-converting enzyme 2 is the main host cell surface receptor interacting with the severe acute respiratory syndrome coronavirus 2 spike glycoprotein to allow viral entry and infection. We speculate that ensuing downregulation of angiotensin-converting enzyme 2 expression may compound the risk conferred by pre-existing comorbidities and critically influence the pathogenesis of hemorrhagic stroke by elevating blood pressure and impairing cerebrovascular endothelial function. Additionally, both age- and/or disease-related immune dysfunction and enhanced catecholamine release secondary to anxiety and stress may also aggravate central nervous system symptoms of severe acute respiratory syndrome coronavirus 2 infection. Thus, assessment of systemic inflammatory biomarkers and tight control of hemodynamic parameters upon admission are crucial to minimize mortality and morbidity in coronavirus disease 2019 patients with central nervous system symptoms suggestive of incipient stroke.

\section{INTRODUCTION}

Since the initial report of cases in Wuhan, Hubei Province, China, in December 2019 and January 2020, coronavirus disease 2019 (COVID-19) has been recognized as a new human disease [1]. The causative agent was identified as a novel coronavirus strain, named severe acute respiratory syndrome coronavirus 2 (SARSCoV-2) by the Coronavirus Study Group (CSG) [2]. The mortality rate of SARS-CoV-2 is lower than those of Middle East respiratory syndrome coronavirus (MERS$\mathrm{CoV})$ and severe acute respiratory syndrome coronavirus
(SARS-CoV) [3]. However, SARS-CoV-2 spreads more rapidly than MERS-CoV and SARS-CoV because viral load and infectiousness peak before or around the time of symptom onset, i.e. much earlier than for both MERS$\mathrm{CoV}$ and SARS-CoV [3]. The high transmissibility of SARS-CoV-2 is denoted by a basic reproduction number $\left(\mathrm{R}_{0}\right)$ of 3.39 over the whole epidemic period [4]. Moreover, COVID-19 can be transmitted by asymptomatic carriers during the incubation period [4-7], probably because they carry viral loads similar to those of symptomatic patients [8]. Although further studies are warranted to ascertain the epidemiological significance of 
the asymptomatic cases, this suggests that asymptomatic transmission may be playing a substantial role in the outbreak [6,9]. Notably, it is increasingly apparent that in many patients, neurological signs and symptoms are the first manifestations of COVID-19 infection $[10,11]$. Although clinical data is not enough, there is still much concern that COVID-19 may increase the risk or trigger the onset of hemorrhagic stroke, especially in older patients. This review summarizes common risk factors for both stroke and COVID-19 severity, and potential mechanisms influencing the onset of hemorrhagic stroke in the elderly.

\section{Identification of SARS-CoV-2 as the causative agent of COVID-19}

Zhou et al. provided the first evidence that COVID-19 is associated with a novel coronavirus strain [12]. They used next-generation sequencing and pan-CoV Polymerase Chain Reaction (PCR) primers to determine the cause of the disease in 7 patients with COVID-19 in Hubei, most of whom were seafood market sellers or deliverers [12]. Their findings significantly strengthened the etiological association reported by investigators from India [13], Switzerland [14] and other places in China [15], who had also isolated the novel coronavirus from patients with COVID-19. These efforts, corroborated by statements from Chinese authorities, conclusively led to identification of SARS-CoV-2 as the causative agent of the COVID-19 outbreak [14].

Since its discovery, the sequence of the complete genome of SARS-CoV-2 has been determined $[13,16,17]$. It has $\sim 29,000$ nucleotides in length and like other CoVs, it contains at least six open reading frames (ORFs) and several accessory genes [13]. According to Chen et al. [15], the genome sequence of SARS-CoV-2 is $89 \%$ identical to the bat SARS-likeCoVZXC21 and $82 \%$ identical to the human SARS-CoV [15]. In addition, phylogenetic analysis indicated that two bat SARS-Like CoVs were the nearest homologs of SARS-CoV-2 [13]. Based on genomic structure and phylogenetic analysis, the subfamily Coronavirinae are divided into four genera, namely Alphacoronavirus, Betacoronavirus, Gammacoronavirus, and Deltacoronavirus [13, 18, 19]. Currently, seven human CoVs have been reported: 229E (HCoV-229E), OC43 (HCoV-OC43), NL63 (HCoVNL63), HKU1 (HCoV-HKU1), SARS-CoV, MERS$\mathrm{CoV}$, and SARS-CoV-2. HCoV-229E and HCoV-NL63 belong to the Alphacoronavirus genus, while $\mathrm{HCoV}$ HKU1, SARS-CoV, MERS-CoV, and HCoV-OC43 are Betacoronavirus members [18]. SARS-CoV-2 is also classified as a novel Betacoronavirus belonging to the subgenus Sarbecovirus of the Coronaviridae family $[13,15]$.
The 3' terminal one-third of SARS-CoV-2 genome sequence encodes four structural proteins, namely spike protein $(\mathrm{S})$, envelope protein $(\mathrm{E})$, membrane protein $(\mathrm{M})$, and nucleocapsid protein $(\mathrm{N})$. Among these, the $\mathrm{S}$ gene is particularly important for receptor binding and host specificity [13]. Infection by $\mathrm{CoV}$ begins with the binding of the $\mathrm{S}$ protein, a surface antigen determining viral tropism, to cell-surface molecules expressed in host cells [20]. As shown in Table 1, host receptors for the seven human CoVs include human aminopeptidase $\mathrm{N}$ (CD13) for HCoV-229E [21]; 9-O-acetylated sialic acid for $\mathrm{HCoV}-\mathrm{OC} 43$ [22]; angiotensin-converting enzyme 2 (ACE2) for SARS-CoV [22]; ACE2 for HCoV-NL63 [23, 24]; 9-O-acetylated sialic acid for HCoV-HKU1 [25, 26]; dipeptidyl peptidase 4 (DPP4) for MERS-CoV [27]; and ACE2 by SARS-CoV-2 [18].

\section{Potential impact of COVID-19 on hemorrhagic stroke in the elderly}

At presentation, the most common symptoms in COVID-19 patients are fever, dry cough, and shortness of breath, whereas headache, diarrhea, and vomiting are more rare [3, 28-30]. However, early neurological symptoms (e.g. headache, epilepsy, and unconsciousness), without obvious respiratory symptoms, have been reported for numerous COVID-19 patients [10, 31]. A 2005 case report by $\mathrm{Xu}$ et al. provided the first direct evidence that SARS-CoV has the ability to infect the central nervous system (CNS) [32]. A predicted cDNA fragment specific for SARS-CoV was amplified by nested RT-PCR from Vero-E6 cell cultures inoculated with a brain tissue extract from a symptomatic patient, and presence of enveloped virus particles, 80-90 nm in diameter, was found by transmission electronic microscopy [32]. Shortly before this finding, another study had reported the case of a 32-year-old woman with SARS whose cerebrospinal fluid tested positive for SARS-CoV [33]. These findings were further supported by experiments in mice that demonstrated the ability of various CoVs to cause CNS infections [34-36]. Indeed, SARS-CoV-2 shares similar characteristics with SARS-CoV, and both anecdotal and statistical data indicate that neurologic symptoms are not common in COVID-19 patients [10]. Since it is well known that cerebral hemorrhage may result from viral infection of the CNS compromising the neurovascular unit [37-40], available evidence strongly suggest that SARS-CoV-2 infection may greatly increase the incidence of hemorrhagic stroke, especially in at-risk patients.

\section{Shared risk factors}

Hypertension is the most important risk factor for cerebral hemorrhage [41, 42]. Of note, for the 138 COVID-19 
Table 1. Human coronavirus species and their receptors.

\begin{tabular}{lcc}
\hline Coronavirus species & Discovery year & Cellular receptor \\
\hline HCoV-229E & 1966 & Human aminopeptidase N (CD13) \\
HCoV-OC43 & 1967 & 9-O-acetylated sialic acid \\
SARS-CoV & 2003 & ACE2 \\
HCoV-NL63 & 2004 & ACE2 \\
HCoV-HKU1 & 2005 & 9-O-acetylated sialic acid \\
MERS-CoV & 2012 & DPP4 \\
SARS-CoV-2 & 2019 & ACE2 \\
\hline
\end{tabular}

confirmed cases analyzed by Wang et al. [30], 43 patients $(31.2 \%)$ were hypertensive, a proportion that reflects, relative to other diseases, the higher susceptibility to SARS-CoV-2 infection conferred by hypertension. Similar results were recently reported by both Guan et al. [26] and the Novel Coronavirus Pneumonia Emergency Response Epidemiology Team [50]. SARS-CoV-2 infection in humans is mediated by binding of the receptor-binding domain (RBD) of the viral $\mathrm{S}$ glycoprotein to ACE2 receptors in host cells, and this in turn may lead to downregulation of ACE2 expression [20, 43]. Since reduced ACE2 expression implies increased Ang II availability, COVID-19 patients with pre-existing hypertension may experience large blood pressure (BP) fluctuations, making them especially susceptible to hemorrhagic stroke episodes.

There is a close relationship between systolic BP variability (SBPV) and poor prognosis of cerebral hemorrhage. Divani et al. reported that elevated SBPV in the first $24 \mathrm{~h}$ of admission was related to unfavorable in-hospital prognosis in patients with intracerebral hemorrhage (ICH) [44]. Since BP elevations resulting from downregulation of ACE2 expression may occur after SARS-CoV-2 infection, higher SBPV may be present on admission in hemorrhagic stroke patients affected by COVID-19. Therefore, the management of $\mathrm{BP}$ might require additional attention during the hyperacute and acute hemorrhagic stroke phases in COVID19 patients, as both high absolute BP levels and high BP fluctuations are main determinants of cerebral hemorrhage prognosis.

Diabetes is also an independent risk factor for hemorrhagic stroke [42]. Huang et al. reported that among 41 patients with laboratory- confirmed SARSCoV-2 infection, 8 (20\%) cases had diabetes; this again represents a higher proportion of comorbidity cases compared with other diseases [45]. Indeed, available data suggest that among COVID-19-confirmed cases with underlying chronic diseases, diabetes ranks second after hypertension $[29,45]$.
Elevated plasma D-dimer levels were associated with increased risk of hemorrhagic stroke [41]. Recently, Chen et al. conducted a retrospective, single-center study including 99 patients with COVID-19 and found elevated D-dimer levels in 36 patients (36\%) [28]; however, mortality rate for this subgroup was not reported. Meanwhile, in a similar study assessing 191 COVID-19confirmed patients, D-dimer greater than $1 \mathrm{mg} / \mathrm{L}$ on admission was associated with significantly increased odds $(\mathrm{p}=0.0033)$ of in-hospital death [46]. Of note, a recently posted pre-print article reporting on 248 consecutive COVID-19 cases in Wuhan found D-dimer elevation $(\geq 0.50 \mathrm{mg} / \mathrm{L})$ in $74.6 \%(185 / 248)$ of the patients. D-dimer levels correlated with disease severity, and values $>2.14 \mathrm{mg} / \mathrm{L}$ predicted in-hospital mortality with a sensitivity of $88.2 \%$ and specificity of $71.3 \%$ [47].

Surprisingly, two recent studies have reported an association between SARS-CoV-2 infection and the incidence of stroke [31, 48]. A single center, retrospective, observational study by $\mathrm{Li}$ et al reported a $5 \%$ risk of ischemic stroke and a $0.5 \%$ risk of cerebral hemorrhage in 221 patients with SARS-CoV-2 infection from Wuhan, China [48]. In this cohort, patients with new onset stroke are obviously older, more likely to present with severe COVID-19 and have the above risk factors including hypertension, diabetes and elevated plasma D-dimer levels [48]. Another study of 214 patients reported 5 (5.7\%) developed acute cerebrovascular diseases including $4(4.6 \%)$ patients with ischemic stroke and $1(1.1 \%)$ with cerebral hemorrhage in severe patients with COVID-19 [31]. Nevertheless, further studies including larger sample sizes, more exhaustive assessment of patients' clinical histories, and additional molecular analysis are clearly needed to determine in which cases stroke is directly triggered by SARS-CoV-2 infection, or it occurs coincidentally [49].

\section{Convergence of inflammatory mediators}

Inflammatory monocyte-macrophages (IMMs) and neutrophils are major sources of cytokines and 
chemokines involved in the pathogenicity of SARSCoV-2 [50]. Some of these factors represent classical inflammatory biomarkers associated with secondary brain injury following cerebral hemorrhage and may have prognostic value in hemorrhagic stroke patients [51-55]. Lattanzi et al. recently reviewed available evidence pointing to the relevance of assessing the neutrophil-to-lymphocyte ratio (NLR) to determine inflammatory status in ICH patients [54]. In turn, newer studies confirmed NLR's predictive value for prognosis of ICH $[56,57]$. Neutrophil-derived matrix metalloproteinases (MMPs) are upregulated after acute $\mathrm{ICH}$, contributing significantly to tissue destruction and activation of neuro-inflammatory cascades [54]. Accordingly, research suggests that it may be possible to mitigate brain damage by early, short-term inhibition of MMPs [53]. Napoli et al. reported that increased concentrations of serum C-reactive protein (CRP), a marker of inflammation, may be an independent predictor of ICH outcome [52]. Nevertheless, it should be considered that interethnic genomic differences may influence CRP status and its predictive values on different stroke phenotypes. Another marker, namely serum neutrophil gelatinaseassociated lipocalin (NGAL), a member of the lipocalin family of proteins associated with transport of small hydrophobic molecules, plays an important role in the innate immune response and has also been identified as an independent predictor for outcome following hemorrhagic stroke [51]. Given that these inflammatory biomarkers have been associated with both SARS-CoV-2-related cytopathic effects and hemorrhagic stroke outcome, it would be worthwhile to explore which changes in inflammatory biomarkers occur after hemorrhagic stroke and their predictive value in patients with and without COVID-19. This would allow to better define reliable indices of hemorrhagic stroke severity and functional recovery.

Substantially reduced peripheral lymphocyte counts were evident in severe COVID-19 cases [28-30, 45, 58]. Xu et al. reported pathological findings of lung, liver, and heart biopsies, as well as blood cell analysis, from a patient who died of COVID-19 [59]. The findings showed infiltration of IMMs in the lung, whereas peripheral CD4 and CD8 $\mathrm{T}$ cells were reduced in number but overactivated. The authors suggested that severe immune injury in this patient was due to overactivation of T cells, manifested by increased representation of highly proinflammatory CCR6+ Th17 CD4 T cell subsets and enhanced cytotoxic capacity of CD8 T cells. These data suggest that although lymphopenia is a common feature in patients with COVID-19, it may be paralleled by a pro-inflammatory phenotypic switching in $\mathrm{T}$ cell subsets that could be critically associated with disease severity and mortality $[9,59]$.
In addition, it was suggested that like SARS-CoV, SARS-CoV-2 also acts on lymphocytes in the respiratory mucosa, leading to a systemic "cytokine storm" concomitant with reduced peripheral blood lymphocytes which impairs cellular immune function [28]. This effect will be clearly potentiated by immune senescence, a well-described phenomenon in many middle-aged and elderly people [60], and aggravated by underlying conditions such as hypertension, diabetes, and cerebrovascular disease. This evidence points to worsened outcomes for patients with COVID-19 and cerebral hemorrhage comorbidity.

\section{Possible mechanisms underlying COVID-19 effects on hemorrhagic stroke in the elderly}

\section{ACE2 expression}

Soon after the COVID-19 outbreak, investigations confirmed that the ACE2 receptor, abundantly expressed in lung alveolar epithelial cells, enables SARS-CoV-2 entry into host cells through the RBD of the virus' $\mathrm{S}$ glycoprotein [12, 61, 62]. The RBD that confers ACE2 binding specificity is part of the S1 subunit of the large ectodomain of the $\mathrm{S}$ protein. The ectodomain contains also an $\mathrm{S} 2$ subunit, which mediates fusion between the viral and host cell membranes [61]. A ternary structure of the RBD of SARS-CoV-2 was obtained by molecular simulation, revealing that the structure is essentially superimposable ( $72 \%$ identity) to that of SARS-CoV, except for a flexible loop with CNGVEGFNC that replaces the rigid loop with CTPPALNC present in SARS-CoV [61]. Further analysis indicated that the unique F486 residue in the flexible loop can penetrate deep into a hydrophobic pocket in ACE2 formed by F28, L79, Y83, and L97 [61].

ACE2 was identified in 2000 as a homolog of the angiotensin-converting enzyme (ACE), although with different substrate specificity [63]. ACE2 primarily acts on angiotensin II (Ang-II), a major bioactive peptide [43], to generate the vasodilatory heptapeptide Ang-(17), while ACE acts on angiotensin I (Ang-I) to generate Ang-II [43]. ACE2 counterbalances the vasopressor effect of the ACE/Ang-II/AT1 axis by stimulating vasodilation through the ACE2/Ang-(1-7)/MasR axis $[64,65]$. Demonstrating the adversarial relationship between ACE and ACE2, Crackower et al. reported that heart function is impaired in ace2-deficient mice, and this effect can be rescued by ablation of ACE expression [66]. ACE2 expression is widely distributed across different cells and tissues. To date, it was identified in epithelial cells of the oral mucosa [62], pulmonary alveolar type II cells [67-69], esophagus upper and stratified epithelial cells, absorptive enterocytes from ileum and colon [69], 
cholangiocytes [70], myocardial cells, kidney proximal tubule cells, and bladder urothelial cells [46]. In addition, ACE2 expression has also been detected in vascular endothelial and smooth muscle cells [71] and in some neurons [43, 64, 71-73], including those in the cardio-respiratory center of the brainstem [43]. The widespread expression of ACE2 is thus consistent with the reported effects of SARS-CoV-2 on multiple tissues and organs. Binding of SARS-CoV-2 to ACE2 receptors in brain blood vessels may trigger the release of proinflammatory cytokines and chemokines such as interleukin-6 (IL-6) and tumor necrosis factor (TNF), leading to activation and extravasation of lymphocyte subsets, neutrophils, and macrophages with subsequent neurological manifestations [74]. On the other hand, neuronal ACE2 expression could also be a significant factor in COVID-19 cases associated with cerebral hemorrhage. Research on the 2003 SARS outbreak concluded that downregulation of ACE2 expression occurred in infected organs, including lungs [75], kidney [43], heart [76], liver [43], and brain [43]. Similarly, a study by Chen et al. reported decreased ACE2 expression in the lungs of COVID-19 patients [61].

Downregulation of ACE2 expression may increase risk of hemorrhagic stroke in several ways: i) ACE2 deficiency in the brain may impair endothelial function in cerebral arteries, leading to a 4-fold elevation in the risk of cerebrovascular events, including hemorrhagic stroke [77]; ii) Downregulation of ACE2 expression may increase local Ang-II levels, which acting on AT1 receptors may rise $\mathrm{BP}$ and facilitate hypertrophy and fibrosis [64]; iii) Decreased ACE2 expression would also lead to reduced generation of Ang (1-7) and depression of Ang (1-7)/MasR signaling, thus preventing its vasodilatory, growth inhibiting, and antifibrotic actions [64, 78] (Figure 1).
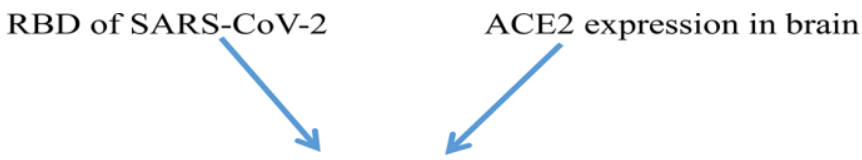

downregulation of ACE2 expression
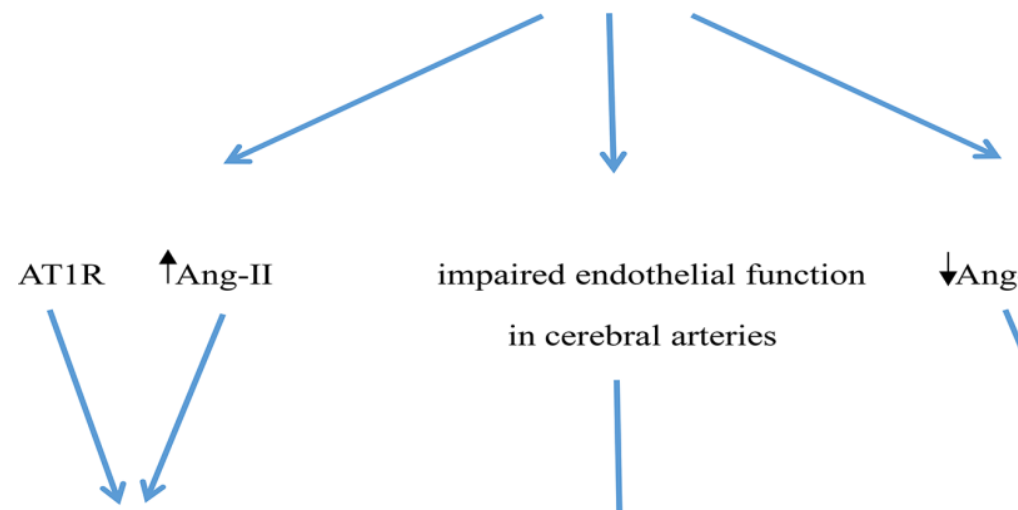

impaired endothelial function

in cerebral arteries

$\downarrow$

$\downarrow$ Ang-(1-7) MasR

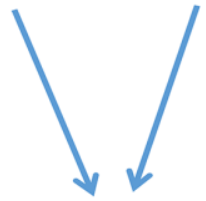

elevated BP,

vasodilation,

hypertrophy,

fibrosis
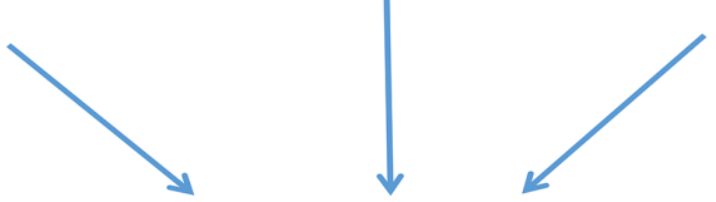

growth inhibition,

antifibrotic

$\uparrow$ risk of hemorrhagic stroke

Figure 1. Potential mechanisms mediating increased risk of hemorrhagic stroke in COVID-19 patients. The RBD of SARS-CoV-2' spike protein interacts with ACE2, leading to ACE2 downregulation. ACE2 deficiency impairs endothelial function in cerebral arteries and determines an increase in Ang-II levels, which elevates BP through activation of AT1 receptors (AT1R). Simultaneously, reduced ACE2 leads to a decrease in Ang (1-7) levels, weakening its vasculo-protective effects mediated by Mas receptor (MasR) activation. 
It calls for special attention the fact that COVID-19 may exacerbate any underlying hypertension and put patients at higher risk for hemorrhagic stroke. Several mechanisms may contribute to hemorrhagic stroke in hypertensive patients infected with SARS-CoV-2. These include fibrinoid necrosis, promoted by increased vascular pressure [79], and extensive structural and functional alterations in endothelium and smooth muscle in intracerebral arteries, often aggravated by atherosclerosis, especially in the elderly [80].

\section{Endothelial dysfunction at the blood-brain barrier}

The BBB is a semi-permeable structure consisting of a well-defined basement membrane and endothelial cells bound by tight junctions that limit the passage of macromolecules into the brain parenchyma. The BBB lies in close apposition to brain cell types, including pericytes, astrocytes, microglia, and neurons, and is especially susceptible to damage by both hypertension and diabetes $[81,82]$. $\mathrm{Xu}$ et al. reported that a chemokine, i.e. the monokine/Mig/CXCL9, induced by IFN-g mostly in glial cells, might be involved in the brain immunopathology triggered by SARS [32]. Elevated Mig levels in the blood are correlated with brain infiltration of $\mathrm{CD}^{+} 8^{+}$monocytes/macrophages and $\mathrm{CD}^{+} \mathrm{T}$ lymphocytes in the brain [32]. Given the similarities between SARS-CoV-2 and SARS-CoV, this mechanism deserves further exploration as it may lead to therapeutic strategies to prevent or attenuate brain pathology in COVID-19 patients.

The BBB is a dynamic and complex structure that helps maintain brain homeostasis and compensates fluctuations in the systemic circulation [83]. Expression of ACE2 in endothelial cells of the BBB may be a gateway for SARS-CoV-2 entry into the brain [83]. Moreover, the ensuing ACE2 downregulation, compounded by age-related ACE2 deficiency in older patients, might further increase endothelial dysfunction and risk of ICH [77]. More studies are needed to ascertain the impact of ACE2 expression at the BBB and its effect on SARS-CoV-2mediated CNS symptoms, particularly ICH.

\section{Immunity and inflammation}

There is accruing evidence that viral CNS infections may cause hemorrhage stroke [37, 39, 84]. The pathogenesis may involve cytokine, chemokine, and protease actions increasing BBB permeability, and damage and/or demise of the neurovascular unit during the necrotizing process [37]. Although the specific mechanisms remain unclear, it is obvious that the type and extent of the immune response triggered by the SARS-CoV-2 determine symptoms severity. A recent study from Anderson et al. revealed that bats, the most likely source of the novel SARS-CoV-2, have evolved a highly specific innate immune response characterized by a large expansion of the type I interferon gene family [85]. While this may clarify the basis of bats' immune resistance to SARS$\mathrm{CoV}-2$, there are still many open questions about the mechanism(s) mediating immune defense against CoV-2 in humans. In this regard, it will be very valuable to ascertain and compare immunological (i.e. $\mathrm{T}$ cell status, cytokine expression) and genetic (i.e. HLA haplotypes) profiles between symptomatic and asymptomatic COVID-19 patients, which have shown to influence responses to recent viral outbreaks [86]. This should allow predicting why high viral replication early in the course of infection would lead to the "cytokine storm" characteristic of severe COVID-19 cases [50].

\section{Anxiety and stress}

The current COVID-19 outbreak has undoubtedly increased anxiety, fear, and stress in many people around the world. Social stress, anxiety, and depression are potential risk factors for hemorrhagic stroke, therefore adequate management of these conditions is a key aspect in primary prevention of cerebrovascular disease [87, 88]. The locus coeruleus, a structure in the brainstem, consists mainly of adrenergic neurons that play a crucial role in the genesis of anxiety by releasing catecholamines that critically influence the stress response [89]. Indeed, research has shown that excessive adrenergic stimulation by catecholamines could lead to severe vasospasm and microcirculation disturbances, thus increasing the risk of hemorrhagic stroke [90].

\section{Aging}

Although people of all ages can be infected, middleaged and elderly people are most severely affected by COVID-19, suggesting that aging is a prominent risk factor. Accordingly, it seems logical that the risk of hemorrhagic stroke in COVID-19 patients would increase significantly with age, although a recent article by Oxley et al reported COVID-19-related stroke episodes occurred in five young patients [91]. Based on available evidence, Camacho et al. concluded that age is a strong risk factor for hemorrhagic stroke, the deadliest stroke type [92]. Their study highlights several age-related processes and pathologies, including cerebral microembolism, white matter lesions, vascular basement membrane thickening, and increased BBB permeability, which determine endothelial damage, changes in vessel elasticity, and ensuing fluctuations in blood flow and pressure that cause loss of autoregulation and increase the risk of ICH [92]. 
Research on both animal models and humans indicated that aging is closely associated with endothelial dysfunction and oxidative stress in cerebral arteries [93-97]. Moreover, studies in rodents suggested that these deleterious effects can be promoted by alterations in the RAS system in aged brains. Specifically, works by Pena-Silva et al. [77] and Labandeira-Garcia et al. [98] suggested that agerelated downregulation of ACE2 and AT2 expression may promote vascular dysfunction because the antiinflammatory/anti-oxidant effects of AngII/AT2 and Ang1-7/MasR signaling are overridden by proinflammatory/pro-oxidant signaling through the AngII/AT1 axis. Although confirmatory data in humans is still needed, these studies provide strong support for the overall concept that brain RAS activity has a critical effect on cerebrovascular function during aging and may contribute to endothelial dysfunction, oxidative stress, and risk of hemorrhagic stroke.

\section{CONCLUSIONS}

COVID-19 emerged as a new human infectious disease caused by SARS-CoV-2, a novel coronavirus. A significant proportion of COVID-19 cases, especially older patients, manifest neurological, rather than respiratory, symptoms on admission and may be at higher risk of developing cerebral hemorrhage. The mechanisms by which COVID-19 may promote hemorrhagic stroke in the elderly are not yet clear, but may involve downregulation of ACE2 expression secondary to SARS-CoV-2 binding to neurovascular ACE2 receptors. This might increase Ang-II expression and decrease Ang (1-7) expression, leading to severe BP elevation. increased BBB permeability, and extensive alterations in endothelium and smooth muscle function in intracerebral arteries. The patients most gravelly affected by COVID-19 have underlying hypertension disease, which greatly increases the risk of hemorrhagic stroke. Since SBPV in the first $24 \mathrm{~h}$ of admission predicts cerebral hemorrhage outcome, special attention should be paid to management of BP in at-risk COVID-19 patients. Predisposing factors may be compounded in COVID-19 patients by the inability of their immune system to efficiently prevent or counteract the pernicious effects of the proinflammatory cytokines released upon infection. In addition, anxiety and stress may lead to enhancement of adrenergic tone and trigger vasospasm and microcirculation disturbances, further contributing to cerebrovascular symptoms. In light of this, exploring the changes in inflammatory biomarkers occurring in COVID-19 patients with CNS symptoms suggestive of incipient stroke would aid diagnosis and treatment to avoid irreversible outcomes.

\section{CONFLICTS OF INTEREST}

The authors report no conflicts of interest in this work.

\section{FUNDING}

This study was supported by "Six Talents" Peak Cultivation Funding Project (No.WSW-246), Jiangsu Province, "Thirteenth Five-Year Plan" Special Fund for Science, Education, and Health (No. RCC201807), Yangzhou City and special funding for the leader of the provincial key specialized science department of Northern Jiangsu People's Hospital.

\section{REFERENCES}

1. Li Q, Guan X, Wu P, Wang X, Zhou L, Tong Y, Ren R, Leung KS, Lau EH, Wong JY, Xing $X$, Xiang N, Wu Y, et al. Early transmission dynamics in wuhan, China, of novel coronavirus-infected pneumonia. N Engl J Med. 2020; 382:1199-207.

https://doi.org/10.1056/NEJMoa2001316

PMID:31995857

2. Gorbalenya AE, Baker SC, Baric RS, de Groot RJ, Drosten C, Gulyaeva AA, Haagmans BL, Lauber C, Leontovich AM, Neuman BW, Penzar D, Perlman S, Poon LL, et al. Severe acute respiratory sydrome-related coronavirus: The species and its viruses-a statement of the Coronavirus Study Group. bioRxiv. 2020. https://doi.org/10.1101/2020.02.07.937862

3. To KK, Tsang OT, Leung WS, Tam AR, Wu TC, Lung DC, Yip CC, Cai JP, Chan JM, Chik TS, Lau DP, Choi CY, Chen $\mathrm{LL}$, et al. Temporal profiles of viral load in posterior oropharyngeal saliva samples and serum antibody responses during infection by SARS-CoV-2: an observational cohort study. Lancet Infect Dis. 2020; 20:565-74.

https://doi.org/10.1016/S1473-3099(20)30196-1 PMID:32213337

4. Li J, Wang $\mathrm{Y}$, Gilmour $\mathrm{S}$, Wang $\mathrm{M}$, Yoneoka $\mathrm{D}$, Wang $\mathrm{Y}$, You X, Gu J, Hao C, Peng L, Du Z, Xu DR, Hao Y. Estimation of the epidemic properties of the 2019 novel coronavirus: A mathematical modeling study. bioRxiv. 2020.

https://doi.org/10.2139/ssrn.3542150

5. Ye F, Xu S, Rong Z, Xu R, Liu X, Deng P, Liu H, Xu X. Delivery of infection from asymptomatic carriers of COVID-19 in a familial cluster. Int J Infect Dis. 2020; 94:133-38.

https://doi.org/10.1016/j.ijid.2020.03.042 PMID:32247826

6. Rothe C, Schunk M, Sothmann P, Bretzel G, Froeschl G, Wallrauch C, Zimmer T, Thiel V, Janke C, Guggemos W, 
Seilmaier M, Drosten C, Vollmar $\mathrm{P}$, et al. Transmission of 2019-nCoV infection from an asymptomatic contact in Germany. N Engl J Med. 2020; 382:970-71.

https://doi.org/10.1056/NEJMc2001468

PMID:32003551

7. Le TQM, Takemura T, Moi ML, Nabeshima T, Nguyen LKH, Hoang VMP, Ung THT, Le TT, Nguyen VS, Pham HQA, Duong TN, Nguyen HT, Ngu DN, et al. Severe Acute Respiratory Syndrome Coronavirus 2 Shedding by Travelers, Vietnam, 2020. Emerg Infect Dis. 2020; 26.

https://doi.org/10.3201/eid2607.200591 PMID:32240079

8. Zou L, Ruan F, Huang $M$, Liang L, Huang $H$, Hong $Z$, Yu J, Kang $\mathrm{M}$, Song $\mathrm{Y}$, Xia J, Guo $\mathrm{Q}$, Song $\mathrm{T}$, He J, et al. SARSCoV-2 viral load in upper respiratory specimens of infected patients. N Engl J Med. 2020; 382:1177-79. https://doi.org/10.1056/NEJMc2001737 PMID:32074444

9. Chan JF, Yuan S, Kok KH, To KK, Chu H, Yang J, Xing F, Liu J, Yip CC, Poon RW, Tsoi HW, Lo SK, Chan KH, et al. A familial cluster of pneumonia associated with the 2019 novel coronavirus indicating person-to-person transmission: a study of a family cluster. Lancet. 2020; 395:514-23.

https://doi.org/10.1016/S0140-6736(20)30154-9 PMID:31986261

10. Mao L, Jin $H$, Wang $M, H u ~ Y$, Chen $S$, He $Q$, Chang J, Hong C, Zhou Y, Wang D, Miao X, Li Y, Hu B. Neurologic Manifestations of Hospitalized Patients With Coronavirus Disease 2019 in Wuhan, China. JAMA Neurol. 2020; e201127.

https://doi.org/10.1001/jamaneurol.2020.1127 PMID:32275288

11. Helms J, Kremer S, Merdji H, Clere-Jehl R, Schenck M, Kummerlen C, Collange O, Boulay C, Fafi-Kremer S, Ohana M, Anheim M, Meziani F. Neurologic Features in Severe SARS-CoV-2 Infection. N Engl J Med. 2020. [Epub ahead of print]. https://doi.org/10.1056/NEJMc2008597 PMID:32294339

12. Zhou $P$, Yang $X L$, Wang $X G$, Hu $B$, Zhang $L$, Zhang $W$, Si $H R$, Zhu Y, Li B, Huang CL, Chen HD, Chen J, Luo Y, et al. A pneumonia outbreak associated with a new coronavirus of probable bat origin. Nature. 2020; 579:270-73.

https://doi.org/10.1038/s41586-020-2012-7 PMID: $\underline{32015507}$

13. Malik YS, Sircar S, Bhat S, Sharun K, Dhama K, Dadar M, Tiwari R, Chaicumpa W. Emerging novel coronavirus (2019-nCoV)-current scenario, evolutionary perspective based on genome analysis and recent developments. Vet Q. 2020; 40:68-76. https://doi.org/10.1080/01652176.2020.1727993 PMID:32036774

14. Riou J, Althaus CL. Pattern of early human-to-human transmission of wuhan 2019 novel coronavirus (2019nCoV), december 2019 to january 2020. Euro Surveill. 2020; 25:2000058.

https://doi.org/10.2807/1560-7917.ES.2020.25.4. 2000058 PMID:32019669

15. Chen J. Pathogenicity and transmissibility of 2019nCoV-a quick overview and comparison with other emerging viruses. Microbes Infect. 2020; 22:69-71. https://doi.org/10.1016/j.micinf.2020.01.004 PMID:32032682

16. Zhu N, Zhang D, Wang W, Li X, Yang B, Song J, Zhao X, Huang B, Shi W, Lu R, Niu P, Zhan F, Ma X, et al, and China Novel Coronavirus Investigating and Research Team. A novel coronavirus from patients with pneumonia in China, 2019. N Engl J Med. 2020; 382:727-33.

https://doi.org/10.1056/NEJMoa2001017 PMID: $\underline{1978945}$

17. Wassenaar TM, Zou Y. 2019_nCoV/SARS-CoV-2: rapid classification of betacoronaviruses and identification of traditional chinese medicine as potential origin of zoonotic coronaviruses. Lett Appl Microbiol. 2020; 70:342-48.

https://doi.org/10.1111/lam.13285

PMID:32060933

18. Pillaiyar T, Meenakshisundaram S, Manickam M. Recent discovery and development of inhibitors targeting coronaviruses. Drug Discov Today. 2020; 25:668-88.

https://doi.org/10.1016/i.drudis.2020.01.015 PMID: $\underline{32006468}$

19. Hui DS, Zumla A. Severe acute respiratory syndrome: historical, epidemiologic, and clinical features. Infect Dis Clin North Am. 2019; 33:869-89.

https://doi.org/10.1016/j.idc.2019.07.001 PMID:31668196

20. Wan Y, Shang J, Graham R, Baric RS, Li F. Receptor recognition by the novel coronavirus from wuhan: an analysis based on decade-long structural studies of SARS coronavirus. J Virol. 2020; 94:e00127-20.

https://doi.org/10.1128/JVI.00127-20

PMID:31996437

21. Yeager $\mathrm{CL}$, Ashmun RA, Williams RK, Cardellichio CB, Shapiro LH, Look AT, Holmes KV. Human aminopeptidase $\mathrm{N}$ is a receptor for human coronavirus 229E. Nature. 1992; 357:420-22.

https://doi.org/10.1038/357420a0 PMID:1350662

22. Li W, Moore MJ, Vasilieva N, Sui J, Wong SK, Berne MA, Somasundaran M, Sullivan JL, Luzuriaga K, Greenough 
TC, Choe H, Farzan M. Angiotensin-converting enzyme 2 is a functional receptor for the SARS coronavirus. Nature. 2003; 426:450-54.

https://doi.org/10.1038/nature02145

PMID:14647384

23. Wu K, Li W, Peng G, Li F. Crystal structure of NL63 respiratory coronavirus receptor-binding domain complexed with its human receptor. Proc Natl Acad Sci USA. 2009; 106:19970-74.

https://doi.org/10.1073/pnas.0908837106

PMID:19901337

24. Li W, Sui J, Huang IC, Kuhn JH, Radoshitzky SR, Marasco WA, Choe H, Farzan M. The $S$ proteins of human coronavirus NL63 and severe acute respiratory syndrome coronavirus bind overlapping regions of ACE2. Virology. 2007; 367:367-74.

https://doi.org/10.1016/j.virol.2007.04.035

PMID:17631932

25. Huang X, Dong W, Milewska A, Golda A, Qi Y, Zhu QK, Marasco WA, Baric RS, Sims AC, Pyrc K, Li W, Sui J. Human coronavirus HKU1 spike protein uses oacetylated sialic acid as an attachment receptor determinant and employs hemagglutinin-esterase protein as a receptor-destroying enzyme. J Virol. 2015; 89:7202-13.

https://doi.org/10.1128/JVI.00854-15

PMID:25926653

26. Butler N, Pewe L, Trandem K, Perlman S. Murine encephalitis caused by HCoV-OC43, a human coronavirus with broad species specificity, is partly immune-mediated. Virology. 2006; 347:410-21.

https://doi.org/10.1016/j.virol.2005.11.044

PMID:16413043

27. van Doremalen N, Miazgowicz KL, Milne-Price $S$, Bushmaker T, Robertson S, Scott D, Kinne J, McLellan JS, Zhu J, Munster VJ. Host species restriction of middle east respiratory syndrome coronavirus through its receptor, dipeptidyl peptidase 4. J Virol. 2014; 88:9220-32.

https://doi.org/10.1128/JVI.00676-14

PMID:24899185

28. Chen N, Zhou M, Dong X, Qu J, Gong F, Han Y, Qiu Y, Wang J, Liu Y, Wei Y, Xia J, Yu T, Zhang X, Zhang L. Epidemiological and clinical characteristics of 99 cases of 2019 novel coronavirus pneumonia in wuhan, China: a descriptive study. Lancet. 2020; 395:507-13. https://doi.org/10.1016/S0140-6736(20)30211-7 PMID:32007143

29. Guan WJ, Ni ZY, Hu Y, Liang WH, Ou CQ, He JX, Liu L, Shan H, Lei Cl, Hui DSC, Du B, Li LJ, Zeng G, et al. Clinical characteristics of 2019 novel coronavirus infection in China. medRxiv. 2020.

https://doi.org/10.1101/2020.02.06.20020974
30. Wang D, Hu B, Hu C, Zhu F, Liu X, Zhang J, Wang B, Xiang $\mathrm{H}$, Cheng Z, Xiong $\mathrm{Y}$, Zhao $\mathrm{Y}$, Li Y, Wang $\mathrm{X}$, Peng $\mathrm{Z}$. Clinical characteristics of 138 hospitalized patients with 2019 novel coronavirus-infected pneumonia in wuhan, China. JAMA. 2020; 323:1061-69.

https://doi.org/10.1001/jama.2020.1585

PMID:32031570

31. Mao L, Wang M, Chen S, He Q, Chang J, Hong C, Zhou Y, Wang D, Li Y, Jin H, Hu B. Neurological Manifestations of Hospitalized Patients with COVID-19 in Wuhan, China: a retrospective case series study. medRxiv. 2020.

https://doi.org/10.1101/2020.02.22.20026500

32. Xu J, Zhong S, Liu J, Li L, Li Y, Wu X, Li Z, Deng P, Zhang J, Zhong $N$, Ding $Y$, Jiang $Y$. Detection of severe acute respiratory syndrome coronavirus in the brain: potential role of the chemokine mig in pathogenesis. Clin Infect Dis. 2005; 41:1089-96. https://doi.org/10.1086/444461 PMID:16163626

33. Lau KK, Yu WC, Chu CM, Lau ST, Sheng B, Yuen KY. Possible central nervous system infection by SARS coronavirus. Emerg Infect Dis. 2004; 10:342-44. https://doi.org/10.3201/eid1002.030638 PMID:15030709

34. Glass WG, Subbarao K, Murphy B, Murphy PM. Mechanisms of host defense following severe acute respiratory syndrome-coronavirus (SARS-CoV) pulmonary infection of mice. J Immunol. 2004; 173:4030-39.

https://doi.org/10.4049/iimmunol.173.6.4030 PMID:15356152

35. Fleming JO, Trousdale MD, Bradbury J, Stohlman SA, Weiner LP. Experimental demyelination induced by coronavirus JHM (MHV-4): molecular identification of a viral determinant of paralytic disease. Microb Pathog. 1987; 3:9-20.

https://doi.org/10.1016/0882-4010(87)90033-7 PMID:2848172

36. Watanabe $\mathrm{R}$, Wege $\mathrm{H}$, ter Meulen V. Adoptive transfer of $\mathrm{EAE}$-like lesions from rats with coronavirus-induced demyelinating encephalomyelitis. Nature. 1983; 305:150-53. https://doi.org/10.1038/305150a0 PMID:6310411

37. Hauer L, Pikija S, Schulte EC, Sztriha LK, Nardone R, Sellner J. Cerebrovascular manifestations of herpes simplex virus infection of the central nervous system: a systematic review. J Neuroinflammation. 2019; 16:19. https://doi.org/10.1186/s12974-019-1409-4 PMID:30696448

38. Sivasankar C, White K, Ayodele M. An unusual etiology of acute spontaneous intracerebral hemorrhage. Neurohospitalist. 2019; 9:41-46. 
https://doi.org/10.1177/1941874418758902 PMID: 30671164

39. Carod Artal FJ. Clinical management of infectious cerebral vasculitides. Expert Rev Neurother. 2016; 16:205-21.

https://doi.org/10.1586/14737175.2015.1134321 PMID:26689107

40. ElShimy G, Mariyam Joy C, Berlin F, Lashin W. Intracranial hemorrhage complicating herpes simplex encephalitis on antiviral therapy: a case report and review of the literature. Case Rep Infect Dis. 2017; 2017:6038146.

https://doi.org/10.1155/2017/6038146

PMID:29057131

41. Johansson $\mathrm{K}$, Jansson JH, Johansson L, Wiklund PG, Nilsson TK, Lind M. D-dimer is associated with firstever intracerebral hemorrhage. Stroke. 2018; 49:2034-39.

https://doi.org/10.1161/STROKEAHA.118.021751 PMID:30354971

42. Senn R, Elkind MS, Montaner J, Christ-Crain M, Katan M. Potential role of blood biomarkers in the management of nontraumatic intracerebral hemorrhage. Cerebrovasc Dis. 2014; 38:395-409. https://doi.org/10.1159/000366470 PMID:25471997

43. Lambert DW, Clarke NE, Turner AJ. Not just angiotensinases: new roles for the angiotensinconverting enzymes. Cell Mol Life Sci. 2010; 67:89-98. https://doi.org/10.1007/s00018-009-0152-x PMID:19763395

44. Divani AA, Liu X, Di Napoli M, Lattanzi S, Ziai W, James ML, Jafarli A, Jafari M, Saver JL, Hemphill JC, Vespa PM, Mayer SA, Petersen A. Blood pressure variability predicts poor in-hospital outcome in spontaneous intracerebral hemorrhage. Stroke. 2019; 50:2023-29. https://doi.org/10.1161/STROKEAHA.119.025514 PMID:31216966

45. Huang C, Wang Y, Li X, Ren L, Zhao J, Hu Y, Zhang L, Fan G, Xu J, Gu X, Cheng Z, Yu T, Xia J, et al. Clinical features of patients infected with 2019 novel coronavirus in wuhan, China. Lancet. 2020; 395:497-506.

https://doi.org/10.1016/S0140-6736(20)30183-5

PMID:31986264

46. Zhou F, Yu T, Du R, Fan G, Liu Y, Liu Z, Xiang J, Wang Y, Song B, Gu X, Guan L, Wei Y, Li H, et al. Clinical course and risk factors for mortality of adult inpatients with COVID-19 in wuhan, China: a retrospective cohort study. Lancet. 2020; 395:1054-62.

https://doi.org/10.1016/S0140-6736(20)30566-3 PMID:32171076

47. Yao Y, Cao J, Wang Q, Liu K, Luo Z, Yu K, Chen X, Hu B, Huang Z. D-dimer as a biomarker for disease severity and mortality in COVID-19 patients: a case control study. PREPRINT (Version 1). Research Square. 2020. https://www.researchsquare.com/article/rs-20850/v1

48. Li Y, Wang M, Zhou Y, Chang J, Xian Y, Mao L, Hong C, Chen S, Wang Y, Wang H, Li M, Jin H, Hu B. Acute cerebrovascular disease following covid-19: a single center, retrospective, observational study. medRxiv. 2020.

https://papers.ssrn.com/sol3/papers.cfm?abstract id= $\underline{3550025}$

49. Sharifi-Razavi A, Karimi N, Rouhani N. COVID-19 and intracerebral haemorrhage: causative or coincidental? New Microbes New Infect. 2020; 35:100669. https://doi.org/10.1016/j.nmni.2020.100669 PMID:32322398

50. Channappanavar R, Perlman S. Pathogenic human coronavirus infections: causes and consequences of cytokine storm and immunopathology. Semin Immunopathol. 2017; 39:529-39. https://doi.org/10.1007/s00281-017-0629-x PMID:28466096

51. Chen S, Chen XC, Lou XH, Qian SQ, Ruan ZW. Determination of serum neutrophil gelatinaseassociated lipocalin as a prognostic biomarker of acute spontaneous intracerebral hemorrhage. Clin Chim Acta. 2019; 492:72-77.

https://doi.org/10.1016/j.cca.2019.02.009 PMID: $\underline{30771300}$

52. Di Napoli $M$, Slevin $M$, Popa-Wagner $A$, Singh $P$, Lattanzi S, Divani AA. Monomeric c-reactive protein and cerebral hemorrhage: from bench to bedside. Front Immunol. 2018; 9:1921.

https://doi.org/10.3389/fimmu.2018.01921 PMID:30254628

53. Lattanzi S, Di Napoli M, Ricci S, Divani AA. Matrix Metalloproteinases in Acute Intracerebral Hemorrhage. Neurotherapeutics. 2020. [Epub ahead of print]. https://doi.org/10.1007/s13311-020-00839-0 PMID:31975152

54. Lattanzi S, Brigo F, Trinka E, Cagnetti C, Di Napoli M, Silvestrini M. Neutrophil-to-lymphocyte ratio in acute cerebral hemorrhage: a system review. Transl Stroke Res. 2019; 10:137-45.

https://doi.org/10.1007/s12975-018-0649-4

PMID:30090954

55. Yan XJ, Yu GF, Jie YQ, Fan XF, Huang Q, Dai WM. Role of galectin-3 in plasma as a predictive biomarker of outcome after acute intracerebral hemorrhage. J Neurol Sci. 2016; 368:121-27.

https://doi.org/10.1016/j.jns.2016.06.071 PMID:27538613 
56. Zhang F, Ren Y, Shi Y, Fu W, Tao C, Li X, Yang M, You C, Xin T. Predictive ability of admission neutrophil to lymphocyte ratio on short-term outcome in patients with spontaneous cerebellar hemorrhage. Medicine (Baltimore). 2019; 98:e16120.

https://doi.org/10.1097/MD.0000000000016120 PMID:31232961

57. Zhang F, Ren Y, Fu W, Yang Z, Wen D, Hu X, Tao C, Li X, You $C$, Xin T, Yang M. Predictive accuracy of neutrophilto-lymphocyte ratio on long-term outcome in patients with spontaneous intracerebral hemorrhage. World Neurosurg. 2019; 125:e651-57.

https://doi.org/10.1016/j.wneu.2019.01.143 PMID: 30716500

58. The Novel Coronavirus Pneumonia Emergency Response Epidemiology Team. The Epidemiological Characteristics of an Outbreak of 2019 Novel Coronavirus Diseases (COVID-19) - China, 2020. Chinese Center for Disease Control and Prevention. 2020; 2:113-122.

59. Xu Z, Shi L, Wang Y, Zhang J, Huang L, Zhang C, Liu S, Zhao P, Liu H, Zhu L, Tai Y, Bai C, Gao T, et al. Pathological findings of COVID-19 associated with acute respiratory distress syndrome. Lancet Respir Med. 2020; 8:420-22.

https://doi.org/10.1016/S2213-2600(20)30076-X PMID:32085846

60. Lutz CT, Quinn LS. Sarcopenia, obesity, and natural killer cell immune senescence in aging: altered cytokine levels as a common mechanism. Aging (Albany NY). 2012; 4:535-46.

https://doi.org/10.18632/aging.100482

PMID:22935594

61. Chen Y, Guo Y, Pan Y, Zhao ZJ. Structure analysis of the receptor binding of 2019-nCoV. Biochem Biophys Res Commun. 2020; 525:135-40.

https://doi.org/10.1016/j.bbrc.2020.02.071

PMID: $\underline{32081428}$

62. Xu H, Zhong L, Deng J, Peng J, Dan H, Zeng X, Li T, Chen $Q$. High expression of ACE2 receptor of 2019nCoV on the epithelial cells of oral mucosa. Int J Oral Sci. 2020; $12: 8$. https://doi.org/10.1038/s41368-020-0074-x PMID:32094336

63. Lazartigues $E$, Feng $\mathrm{Y}$, Lavoie JL. The two fACEs of the tissue renin-angiotensin systems: implication in cardiovascular diseases. Curr Pharm Des. 2007; 13:1231-45.

https://doi.org/10.2174/138161207780618911 PMID:17504232

64. Deshotels MR, Xia H, Sriramula S, Lazartigues E, Filipeanu CM. Angiotensin II mediates angiotensin converting enzyme type 2 internalization and degradation through an angiotensin II type I receptordependent mechanism. Hypertension. 2014; 64:1368-75.

https://doi.org/10.1161/HYPERTENSIONAHA.114.03743 PMID:25225202

65. Fan $X$, Wang $Y$, Sun $K$, Zhang $W$, Yang $X$, Wang $S$, Zhen Y, Wang J, Li W, Han Y, Liu T, Wang X, Chen J, et al, and Study Group for Pharmacogenomic Based Antihypertensive Drugs Selection, Effects and Side Effects, in Rural Area Chinese. Polymorphisms of ACE2 gene are associated with essential hypertension and antihypertensive effects of captopril in women. Clin Pharmacol Ther. 2007; 82:187-96.

https://doi.org/10.1038/sj.clpt.6100214

PMID: 17473847

66. Crackower MA, Sarao R, Oudit GY, Yagil C, Kozieradzki I, Scanga SE, Oliveira-dos-Santos AJ, da Costa J, Zhang L, Pei Y, Scholey J, Ferrario CM, Manoukian AS, et al. Angiotensin-converting enzyme 2 is an essential regulator of heart function. Nature. 2002; 417:822-28. https://doi.org/10.1038/nature00786 PMID:12075344

67. Zou X, Chen K, Zou J, Han P, Hao J, Han Z. Single-cell RNA-seq data analysis on the receptor ACE2 expression reveals the potential risk of different human organs vulnerable to 2019-nCoV infection. Front Med. 2020; 14:185-92.

https://doi.org/10.1007/s11684-020-0754-0 PMID: 32170560

68. Zhao Y, Zhao ZX, Wang YJ, Zhou YQ, Ma Y, Zuo W. Single-cell RNA expression profiling of ACE2, the putative receptor of Wuhan 2019-nCov. bioRxiv. 2020. https://www.biorxiv.org/content/10.1101/2020.01.26. 919985v1

69. Zhang H, Kang ZJ, Gong HY, Xu D, Wang J, Li ZF, Cui XG, Xiao JR, Meng T, Zhou W, Liu JM, Xu HJ. The digestive system is a potential route of 2019-nCov infection: a bioinformatics analysis based on single-cell transcriptomes. bioRxiv. 2020.

https://www.biorxiv.org/content/10.1101/2020.01.30. $\underline{927806 \mathrm{v} 1}$

70. Chai XQ, Hu LF, Zhang Y, Han WY, Lu Z, Ke AW, Zhou J, Shi GM, Fang N, Fan J, Cai JB, Fan J, Lan F. Specific ACE2 expression in cholangiocytes may cause liver damage after 2019-nCoV infection. bioRxiv. 2020.

https://www.biorxiv.org/content/10.1101/2020.02.03. 931766v1

71. Hamming I, Timens W, Bulthuis ML, Lely AT, Navis G, van Goor H. Tissue distribution of ACE2 protein, the functional receptor for SARS coronavirus. A first step in understanding SARS pathogenesis. J Pathol. 2004; 203:631-37. 
https://doi.org/10.1002/path.1570

PMID:15141377

72. Doobay MF, Talman LS, Obr TD, Tian X, Davisson RL, Lazartigues E. Differential expression of neuronal ACE2 in transgenic mice with overexpression of the brain renin-angiotensin system. Am J Physiol Regul Integr Comp Physiol. 2007; 292:R373-81.

https://doi.org/10.1152/ajpregu.00292.2006

PMID: 16946085

73. Siniscalchi A, Gallelli L. Could COVID-19 represent a negative prognostic factor in patients with stroke? Infect Control Hosp Epidemiol. 2020:1.

https://doi.org/10.1017/ice.2020.146

PMID:32307025

74. Newton AH, Cardani A, Braciale TJ. The host immune response in respiratory virus infection: balancing virus clearance and immunopathology. Semin Immunopathol. 2016; 38:471-82.

https://doi.org/10.1007/s00281-016-0558-0

PMID:26965109

75. Kuba K, Imai Y, Rao S, Gao H, Guo F, Guan B, Huan Y, Yang $P$, Zhang $Y$, Deng W, Bao L, Zhang B, Liu G, et al. A crucial role of angiotensin converting enzyme 2 (ACE2) in SARS coronavirus-induced lung injury. Nat Med. 2005; 11:875-79.

https://doi.org/10.1038/nm1267

PMID:16007097

76. Oudit GY, Kassiri Z, Jiang C, Liu PP, Poutanen SM, Penninger JM, Butany J. SARS-coronavirus modulation of myocardial ACE2 expression and inflammation in patients with SARS. Eur J Clin Invest. 2009; 39:618-25. https://doi.org/10.1111/j.1365-2362.2009.02153.x PMID:19453650

77. Peña Silva RA, Chu Y, Miller JD, Mitchell IJ, Penninger JM, Faraci FM, Heistad DD. Impact of ACE2 deficiency and oxidative stress on cerebrovascular function with aging. Stroke. 2012; 43:3358-63.

https://doi.org/10.1161/STROKEAHA.112.667063 PMID:23160880

78. Santos RA, Simoes e Silva AC, Maric C, Silva DM, Machado RP, de Buhr I, Heringer-Walther S, Pinheiro SV, Lopes MT, Bader M, Mendes EP, Lemos VS, Campagnole-Santos MJ, et al. Angiotensin-(1-7) is an endogenous ligand for the $\mathrm{G}$ protein-coupled receptor mas. Proc Natl Acad Sci USA. 2003; 100:8258-63.

https://doi.org/10.1073/pnas.1432869100 PMID:12829792

79. Lammie GA. Hypertensive cerebral small vessel disease and stroke. Brain Pathol. 2002; 12:358-70. https://doi.org/10.1111/j.1750-3639.2002.tb00450.x PMID:12146804

80. Johansson BB. Hypertension mechanisms causing stroke. Clin Exp Pharmacol Physiol. 1999; 26:563-65. https://doi.org/10.1046/j.1440-1681.1999.03081.x PMID:10405790

81. Hawkins BT, Lundeen TF, Norwood KM, Brooks HL, Egleton RD. Increased blood-brain barrier permeability and altered tight junctions in experimental diabetes in the rat: contribution of hyperglycaemia and matrix metalloproteinases. Diabetologia. 2007; 50:202-11. https://doi.org/10.1007/s00125-006-0485-z PMID:17143608

82. Huber JD, Egleton RD, Davis TP. Molecular physiology and pathophysiology of tight junctions in the bloodbrain barrier. Trends Neurosci. 2001; 24:719-25. https://doi.org/10.1016/s0166-2236(00)02004-x PMID:11718877

83. Huber JD. Diabetes, cognitive function, and the bloodbrain barrier. Curr Pharm Des. 2008; 14:1594-600. https://doi.org/10.2174/138161208784705441 PMID: 18673200

84. Joshi P. Multiple strokes associated with herpes simplex virus type-2 infection: case report. J Neurovirol. 2016; 22:251-53.

https://doi.org/10.1007/s13365-015-0385-4

PMID:26443565

85. Anderson DE, Cui J, Ye Q, Huang B, Zu W, Gong J, Liu W, Kim SY, Yan BG, Sigmundsson K, Lim XF, Ye F, Niu P, et al. Orthogonal genome-wide screenings in bat cells identify MTHFD1 as a target of broad antiviral therapy. bioRxiv 2020.

https://doi.org/10.1101/2020.03.29.014209

86. Shi Y, Wang Y, Shao C, Huang J, Gan J, Huang X, Bucci E, Piacentini M, Ippolito G, Melino G. COVID-19 infection: the perspectives on immune responses. Cell Death Differ. 2020; 27:1451-54.

https://doi.org/10.1038/s41418-020-0530-3

PMID: $\underline{32205856}$

87. Schneck MJ. Is psychological stress a risk factor for cerebrovascular disease? Neuroepidemiology. 1997; 16:174-79.

https://doi.org/10.1159/000109684

PMID: 9267833

88. Jackson CA, Sudlow CL, Mishra GD. Psychological distress and risk of myocardial infarction and stroke in the 45 and up study. Circ Cardiovasc Qual Outcomes. 2018; 11:e004500.

https://doi.org/10.1161/CIRCOUTCOMES.117.004500 PMID:30354546

89. Lader $M$. The peripheral and central role of the catecholamines in the mechanisms of anxiety. Int Pharmacopsychiatry. 1974; 9:125-37. https://doi.org/10.1159/000468126 PMID:4154319

90. Santos JR, Brofferio A, Viana B, Pacak K. 
Catecholamine-induced cardiomyopathy in pheochromocytoma: how to manage a rare complication in a rare disease? Horm Metab Res. 2019; 51:458-69.

https://doi.org/10.1055/a-0669-9556

PMID:30227459

91. Oxley TJ, Mocco J, Majidi S, Kellner CP, Shoirah H, Singh IP, De Leacy RA, Shigematsu T, Ladner TR, Yaeger KA, Skliut M, Weinberger J, Dangayach NS, et al. Largevessel stroke as a presenting feature of covid-19 in the young. N Engl J Med. 2020; 382:e60.

https://doi.org/10.1056/NEJMc2009787

PMID:32343504

92. Camacho $E$, LoPresti MA, Bruce $S$, Lin D, Abraham M, Appelboom G, Taylor B, McDowell M, DuBois B, Sathe $\mathrm{M}$, Sander Connolly $\mathrm{E}$. The role of age in intracerebral hemorrhages. J Clin Neurosci. 2015; 22:1867-70.

https://doi.org/10.1016/j.jocn.2015.04.020

PMID:26375325

93. Mayhan WG, Arrick DM, Sharpe GM, Sun H. Agerelated alterations in reactivity of cerebral arterioles: role of oxidative stress. Microcirculation. 2008; 15:225-36.

https://doi.org/10.1080/10739680701641421

PMID:18386218

94. Park L, Anrather J, Girouard H, Zhou P, ladecola C. Nox2-derived reactive oxygen species mediate neurovascular dysregulation in the aging mouse brain. J Cereb Blood Flow Metab. 2007; 27:1908-18. https://doi.org/10.1038/sj.jcbfm.9600491

PMID:17429347

95. Modrick ML, Didion SP, Sigmund CD, Faraci FM. Role of oxidative stress and AT1 receptors in cerebral vascular dysfunction with aging. Am J Physiol Heart Circ Physiol. 2009; 296:H1914-19.

https://doi.org/10.1152/ajpheart.00300.2009 PMID:19395552

96. Xu X, Wang B, Ren C, Hu J, Greenberg DA, Chen T, Xie L, Jin K. Age-related impairment of vascular structure and functions. Aging Dis. 2017; 8:590-610. https://doi.org/10.14336/AD.2017.0430 PMID:28966804

97. Bachschmid MM, Schildknecht S, Matsui R, Zee R, Haeussler D, Cohen RA, Pimental D, van der Loo B. Vascular aging: chronic oxidative stress and impairment of redox signaling-consequences for vascular homeostasis and disease. Ann Med. 2013; 45:17-36.

https://doi.org/10.3109/07853890.2011.645498 PMID:22380696

98. Labandeira-Garcia JL, Rodríguez-Perez Al, Garrido-Gil P, Rodriguez-Pallares J, Lanciego JL, Guerra MJ. Brain renin-angiotensin system and microglial polarization: implications for aging and neurodegeneration. Front Aging Neurosci. 2017; 9:129.

https://doi.org/10.3389/fnagi.2017.00129

PMID:28515690 